Asian-Australasian Journal of Food Safety and Security

ISSN 2523-1073 (Print) 2523-2983(Online) www.ebupress.com/journal/aajfss

\title{
Article \\ Semi-intensive rearing of Turkey (Meleagris Gallopavo) in some selected areas of Bangladesh
}

\author{
Md.Yousuf Ali $^{1 *}$, Nathu Ram Sarker ${ }^{2}$, Md. Ershaduzzaman ${ }^{2}$, Razia Khatun ${ }^{2}$, Shamim Ahmed $^{2}$ Md. Ashadul \\ Alam $^{2}$, Most. Sumona Akter ${ }^{3}$, Sirazum Munira ${ }^{1}$, Shahidur Rahman ${ }^{1}$ and US Alam ${ }^{1}$ \\ ${ }^{1}$ Bangladesh Livestock Research Institute, Regional Station, Baghabari, Sirajgonj-6770, Bangladesh \\ ${ }^{2}$ 1Bangladesh Livestock Research Institute, Savar, Dhaka-1341, Bangladesh \\ ${ }^{3}$ Department of Livestock Services, Khamarbari, Dhaka, Bangladesh
}

*Corresponding author: Md. Yousuf Ali, Bangladesh Livestock Research Institute, Regional Station, Shahjadpur, Sirajgonj, Bangladesh. E-mail: 113yousuf.bau@gmail.com, myousuf@blri.gov.bd

Received: 29 April 2019/Accepted: 28 May 2019/ Published: 30 May 2019

\begin{abstract}
There were 17 districts under Dhaka, Chottogram, Sylhet, Rajshahi, Khulna and Mymensingh divisions selected for this study on the basis of Turkey farming. The total 52 number of farmers interviewed to conduct this study. Turkey rearing is a profitable agricultural practice to meet the protein requirement in developing countries like Bangladesh. This is not only a source of protein but also a rich source of minerals and vitamins. The semi-intensive rearing of turkey requires low capital investment and labor cost. The main objectives of the study were to know the present status of feeding and rearing system, problems and prospects and benefit cost ratio of turkey rearing in Bangladesh. The information that collected from the respondents were age, education, main occupation, family members, training, annual income, number of turkey in each batch, name of strain, mortality rate, vaccination and medication practice, current situation of antibiotic and growth promoter use, use of footbath, use of disinfectant for spraying in inside and outside of the farm, percentage of antibiotic and feed additives withdrawal period before marketing, source of vaccine and medicine at farmer level, consultants of the farmers for vaccine and medicine specially antibiotic use, vaccination and medication cost in a batch. The average cost for production of one kg meat is BDT 231.177 and average market price of one $\mathrm{kg}$ meat was about BDT 452.34.
\end{abstract}

Keywords: guinea fowl; vaccination; medication; mortality; benefit cost ratio

\section{Introduction}

Bangladesh is a small highly populated sovereign country comprising 147,570 square kilometers in south Asia. The poultry meat fills 37\% demand of domestic meat requirement (Begum et al., 2011) and the cultivation of turkey bird is less common in Bangladesh but this sector is expanding day by day (Jahan et al., 2018). Turkey meat is the second largest contributor to the world's poultry meat production after chicken (Aslam et al., 2012). According to turkey management guide 2012, the turkey has high dressing percentage that could amount to $87 \%$ of slaughter weight. By exploring the turkey rearing, it can be a strong alternative source for protein. This bird bears an aesthetic value and meat is often considered as a luxury meat (Asaduzzaman $e t$ al., 2017). Turkey is also a good insect forager, it will be a good candidate for managing the in insect in few crop field (Grimes et al., 2007) and better quality of meat, survival in arid environmental condition and heat tolerance create the new window in agriculture (Yakubu et al., 2013). The young people mainly are engaging in turkey farming as a profitable business, because turkey rearing is quite easy and less susceptible to disease than the traditional poultry. Now it is playing an important subsector in agricultural arena in Bangladesh (Jahan et al., 2018). But the rearing of turkey in Bangladesh is not fully explored. Turkey rearing is an important and a profitable agricultural practice, with an increasing global demand for animal meat (Yakubu et al., 2013). The nutritional value of turkey is quite similar with other meat but the amount of fat and fatty acid is lower (USDA 
nutritional value database, 2019). It also contains the rich omega-3 fatty acid (22.2 $\mathrm{mg})$ and omega- 6 fatty acid $(122 \mathrm{mg}$ ) and the rich source of minerals like selenium $(27.1 \mathrm{mcg})$, magnesium $(31.1 \mathrm{mg})$, sodium $(54.4 \mathrm{mg})$, calcium $(11.1 \mathrm{mg})$, potassium $(325 \mathrm{mg})$ and few other minerals, in 100 grams of meat. Turkey is an excellent source vitamin like Riboflavin $(0.1 \mathrm{mg})$, Niacin $(6.9 \mathrm{mg})$, Vitamin B-06 (0.6 mg), Folate (8.9 mcg), vitamin B$12(0.5 \mathrm{mcg})$ and pantothenic acid $(0.8 \mathrm{mg})$. Due the leanest nature of the meat, people like to consume it.

\section{Materials and Methods}

\subsection{Investigation area and duration of study}

This study has done on 52 farmers of 17 districts of Bangladesh. The turkey farm from Dhaka, Sylhet, Kumilla, Mymenshingh, Norshingdhi, Chittagong, Tangail, Brammanbaria, Chandpur, Barisal, Feni, Rajshahi, Munshiganj, Gazipur, Faridpur, Nayaranganj, and Madaripur were selected for our investigation. The study was carried out from January 2016 to January 2017. The map showed the farm area of Bangladesh. This map downloaded from lged.gov.bd. (LGED website, 2019).

\subsection{Experimental design}

A special experimental model was designed to carry out the study. The questionnaire and interview with the selected farmer was set up in keeping mind the objectives our research, future application, story of success and failure of farmer, their socioeconomic condition, their time and dedication for collecting our data. The questionnaire and interview was pretested on few farmers in different parts of the country for judgment of suitability and assessing the sustainability of data for application.

\subsection{Sampling technique and sample size}

A multistage sampling procedure was followed for the study and selection of farmer was done only who were engaged in turkey bird farming in 17 districts of rural and urban area of Bangladesh. We didn't find any database of turkey farmers from government of the people's republic of Bangladesh. We made a list of 150 farmers across the country via the information published by daily news paper, electronic media and from social website. Finally, we selected 52 farmers based on our selection parameters.

\subsection{Data collection}

The data was collected through direct firm visit, interview with farmer and farm caretaker, analysis of record keeping book. Primarily, we focused on farmer's socioeconomic condition by taking the information like their age, sex, level of education and some other personal information. Then we focused the information of number of birds, types of shed, direction of shed, air maintenance, lighting facility and lighting schedule, Temperature management, litter materials and its thickness, duration litter use and recycling of litter material, source and price of chicks, cost of production, marketing, feeding and treatment.

\subsection{Analysis of data}

The collected data was compiled, tabulated where needed and analyzed. The qualitative data was converted in quantitative form by numerical score. For analysis of data we used Microsoft office excel program (Microsoft office excel 2007).

\section{Results and Discussion}

\subsection{Demographic information of farmers}

The investigation of fifty two farmers was carried out in nineteen districts across the Bangladesh. To find out their socioeconomic information data of age, educational level, and whether they got technical support were collected. The average age of farmer is and the level of education varies from primary to post graduate degree (Table 1).

\subsection{Number of birds}

The number of birds depends on several parameters like availability of fund and investment, work force, price of chick, disease control, and market price of final product, farmer's experience, area of farm and overall sound management of farm. The number of birds of per farmer, starts from five to 345 and average number of birds is 86. 


\subsection{Shed management}

In the investigation area, we found three types of shed like Kacha, concrete and semi-bricks. Most of the farmers, 24, made Kacha shed and 21 farmers use semi bricks to build their shed. A few number of farmer use concrete for their shed construction (Figure 1).

\subsection{Direction and environmental condition of shed}

The direction of shed has made in two ways east west direction and north south direction. The majority number of farmer about $64 \%$ constructed their shed in north south direction and other $36 \%$ farmers constructed their shed in east west direction. All the farms have the facility of air maintenance, lighting and lighting schedule and temperature regulation.

\subsection{Litter materials used}

The litter material consist mainly saw dust, rice husk and sand. Most of the farm (61.5\%) use sand as litter material, 25\% use rice husk other use saw dust. The duration of letter use varies from 15 days to 60 days. Most of the farmers about $95 \%$ use their litter for 30 days, about $2 \%$ of farmer use their litter for 15 days and less than one percent of farmer use litter for 60 days. The selected farmer, approximately $85 \%$ don't reuse their litter material. Recycling of litter material is less common in rural area.

\subsection{Production performance of turkey farming}

The average productive and reproductive performance of turkey is given in Table 2.

\subsection{Disease management}

Different types of disease outbreak occur and the most common diseases are new-castle disease, Gumboro, Coccidiosis, salmonella, avian-influenza and coli-becillosis.

\subsection{Marketing}

Most of the farmer sell their egg, chick and mature Tom and hen in the nearby market. Sometimes they go remote market to get their desired price. Few of them, use social website to advertise their product. The average chick and mature turkey price is near same in all the districts (Table 3).

Table 1. Demographic information of turkey farmers.

\begin{tabular}{lllll}
\hline Serial No. & Educational qualification & Percentage & Average flock size & Farmer type \\
\hline 01 & PEC & $3.85 \%$ & 67 & small \\
02 & JSC & $5.76 \%$ & 92 & Small \\
03 & SSC & $44.23 \%$ & 89 & Small \\
04 & HSC & $34.62 \%$ & 68 & Small \\
05 & Graduation & $9.62 \%$ & 169 & Medium and Small \\
06 & Post Graduation & $3.85 \%$ & 120 & Medium \\
\hline
\end{tabular}

Table 2. Production performance of turkey data obtained from survey.

\begin{tabular}{lll}
\hline Serial No. & Parameter & Average value \\
\hline 01 & First Lay of egg & 26 weeks \\
02 & No eggs laid (/Year) & 120 \\
03 & Price of egg(one) & $158.2 \mathrm{BDT}$ \\
04 & Wt of egg $(\mathrm{g})$ & $82.04 \mathrm{~g}$ \\
05 & Matured Wt $(\mathrm{kg})$ & $7.26 \mathrm{~kg}$ \\
06 & Doc Wt $(\mathrm{g})$ & 61.62 \\
\hline
\end{tabular}


Table 3. Marketing system of turkey.

\begin{tabular}{lllll}
\hline Serial No. & District & $\begin{array}{l}\text { Average cost of } \\
\text { production }(\mathbf{T k} / \mathbf{k g})\end{array}$ & $\begin{array}{l}\text { Average selling price } \\
(\mathbf{T k} / \mathbf{k g})\end{array}$ & Marketing area \\
\hline 01 & Dhaka & 214.38 & 460.00 & Near market and surrounding area \\
02 & Sylhet & 295 & 475 & Near market and surrounding area \\
& & & Near market \\
03 & Comilla & 230 & 465 & Near market \\
04 & Mymensingh & 237.5 & 437.5 & Near market \\
06 & Narshingdhi & 221.25 & 450 & Near market \\
07 & Chottogram & 195 & 465 & Near market \\
08 & Rajshahi & 200 & 450 & Near market \\
09 & Feni & 211 & 426 & Near market \\
10 & Barisal & 270 & 450 & Near market \\
11 & Munshiganj & 250 & 450 & Near market \\
12 & Tangail & 230 & 450 & \\
\hline
\end{tabular}

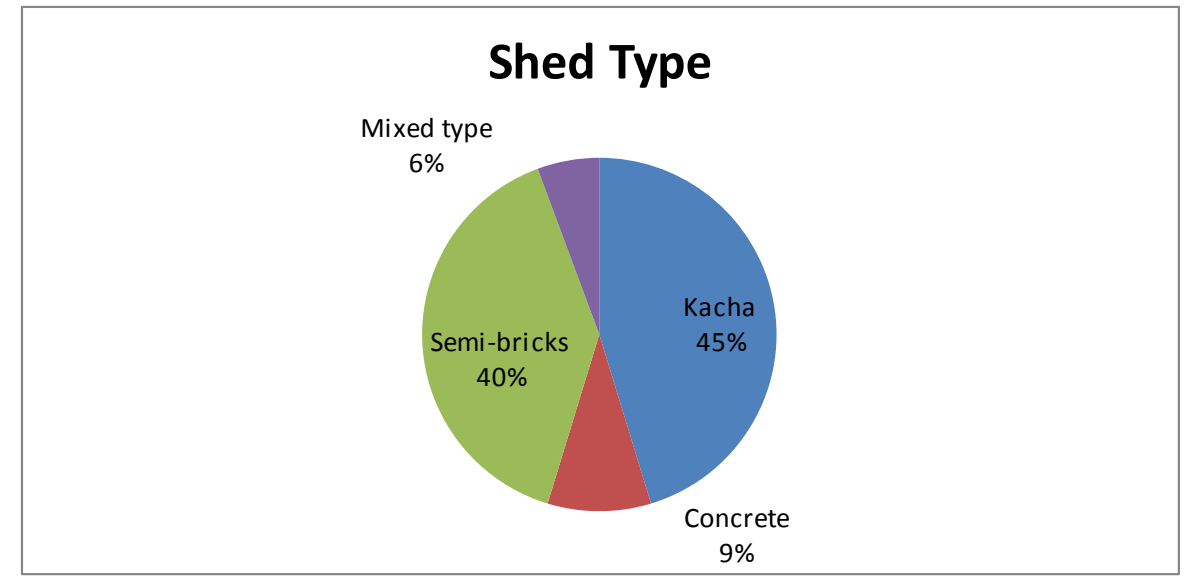

Figure 1. Different types of shed used.

\section{Discussion}

Turkey cultivation is not too much new in Bangladesh. Domestic rearing in the rural area is quite common for last two decades. The number of turkey farm has established by the young entrepreneurs in last few years and most of the farm operated by the male people (98\%) and only $2 \%$ of farms are operating by female entrepreneurs. The story of success is very common, because all our selected farmers are educated. About $80 \%$ the farmers completed secondary and higher secondary education and about $10 \%$ of farmers completed their graduation, which bears a very positive signal for flourishing the turkey farming and creating future stable economy for the country. We observed that most of the farm established in keeping mind for ornamental use. The easy farm management, less disease outbreak, high amount of market price and profit, development of electronic communicative device and their applications helped to expand their farm and set up new ones. The farm owner uses their traditional knowledge of rearing domestic chicken and duck for farm management. The farmers collect chicks of different age from one to 35 days of age. They think that home district town is the best option for collection of chicks. The prize of chicks surprisingly varies from town to town. As for example, the farmers in Dhaka district have to spend about 1500 BDT to buy a single chick, whereas people from Narshingdhi have to cost 250-300 BDT to buy a chick. So it is clear that there is mismanagement in market price. All the farms use litter material and thickness of litter varies from season to season. They like to use as litter material, rice husk, saw dust and sand. The average time of litter material change is 28 days and recycling of litter material is less common. Disease outbreak is less common when the flock size is small.

\section{Conclusions}

From the above study it may conclude as semi-intensive turkey rearing can play a vital role in terms of protein supply as well as a potential economic source of rural people specially for unemployed students in our country. 


\section{Conflict of interest}

None to declare.

\section{References}

Asaduzzaman M, U Salma, HS Ali, MA Hamid and AG Miah, 2017. Problems and prospects of turkey (Meleagris gallopavo) production in Bangladesh. Res. Agric. Livest., Fish., 4: 77-90.

Aslam ML, John WM Bastiaansen, Martin G Elferink, Hendrik-Jan Megens, Richard PMA Crooijmans, Le Ann Blomberg, Robert C Fleischer, Curtis P Van Tassell, Tad S Sonstegard, Steven G Schroeder, Martien AM Groenen and Julie A Long, 2012. Whole genome SNP discovery and analysis of genetic diversity in Turkey (Meleagris gallopavo): http://www.biomedcentral.com/1471-2164/13/391

Begum IA, MJ Alam, J Buysse, A Frija and G Van Huylenbroeck, 2011. A comparative efficiency analysis of poultry farming systems in Bangladesh: A Data Envelopment Analysis approach. Applied Economics, 44: 3737-3747.

Grimes J, J Beranger, M Bender and M Walters, 2007. How to raise heritage turkey on pasture. American livestock Breeds conservancy Pittsboro, NC27312 USA. Headquarters, 233 S.WAckesDrive, 11th floor Chicago, Illinois- 60606.

Jahan B, A Ashraf, MA Rahman, MHR Molla, SH Chowdhury and FO Megwalu, 2018. Rearing of high yielding turkey poults: problems and future prospects in Bangladesh: a review. SF J Biotechnol Biomed Eng., 1: 1008.

Local Government Engineering Department (LGED) Website: www.lged.gov.bd/Acessed in 3rd April, 2019.

Turkey Management Guide, 2012. Central poultry development organization (SR), Hessarghatta, Bangalore 560088, Website: http://www.cpdosrbng.Kar.nic.in. Accessed in January 2019.

Yakubu A, K Abimiku, AIS Musa, KO Idahor and OM Akinsola, 2013. Assessment of flock structure, preference in selection and traits of economic importance of domestic Turkey (Meleagris gallopavo) genetic resources in Nasarawa state, Nigeria. Livest. Res. Rural Dev. 25:18 